\title{
CÉlok ÉS KÖVETKEZMÉNYEK: TANÜGYIRÁNYÍTÁSUNK ÁTALAKÍTÁSA
}

\author{
GYÖRGYI ZOLTÁN
}

A tanulmány egyrészt arra a kérdésre igyekszik válaszolni, hogy az oktatásirányítás 2010 utáni változásai mennyire voltak összhangban az uniós elvárásokkal, másrészt, hogy az új irányítási rendszer mennyiben s mely elemeiben segítette, illetve gátolta ezeket a kormányzati oktatáspolitikai törekvéseket. A szerző úgy látja, hogy oktatásirányításunk sokkal inkább az öncélú bezárkózás jeleit mutatja, mintsem a korszerű, az egyéni igényekre reagáló, a lemaradókkal is törődő oktatásét. Csak érintőlegesen veszi figyelembe az uniós célokat, s a széles lakossági rétegekkel való együttmüködés helyett igyekszik a nyilvánosság teljes kizárásával működtetni a rendszert. Mindez hozzájárul a magyar oktatás teljesítményének visszaeséséhez.

Kulcsszavakः oktatásirányítás, oktatáspolitika, centralizáció

The study highlights, on the one hand, the extent to which changes in education governance after 2010 were in line with EU expectations and, on the other hand, the extent to which elements of the new governance system helped or hindered these governmental education policy efforts. The author sees that Hungarian education management has signs of a self-locking system, instead of a modern, responsive and reflective education that cares for the disadvantage region and disadvantage people. It barely takes EU objectives into account, and instead of cooperation of the stakeholders of the education, rather works without them. All this contributes to the decline in the performance of Hungarian education.

Keywords: education in Hungary, education governance, education policy, centralisation of education

\section{Bevezetés}

$\mathrm{E}$ gy oktatási rendszer sikeressége makro- és mikroszintü tényezök együttes hatásának eredménye. Az összefüggések feltárása nem könnyü, már csak azért sem, mert a sikeresség mérése még akkor sem egyértelmű, ha le is egyszerűsítenénk

Levelező szerző: Györgyi Zoltán. E-mail: gyorgyiz@ella.hu 
a tanulói eredményességre: befolyásolja a mérés tárgya, módja és időpontja, értékelése pedig függ az adott társadalmi-gazdasági kontextustól. Bár a tanulói eredményesség kulcsszereplője a tanár, illetve az oktatás mikrokörnyezete, ez nem független az oktatás irányítási, igazgatási, finanszírozási rendszerétől, vagyis azoktól a feltételektől, amelyek a tanári munkát, a tanulást és a tanulói pályautakat befolyásolják. Az ezzel kapcsolatos célokat és eszközöket az oktatáspolitika határozza meg, a megvalósítás pedig a tanügyirányitás, s azon belül a tanügyigazgatás feladata.

A három fogalom egymástól való elhatárolása nem teljesen egyértelmü. Az oktatáspolitika mint szakpolitika a föbb irányvonalakat jelöli ki, meghatározza az oktatási rendszer törvényes kereteit, s teszi ezt politikai erővonalak, vagyis politikai szándékok, illetve politikai érdekek mentén. A tanügyigazgatás sokat használt kifejezés, de a fogalmat használó szakirodalomban nem találjuk egységes definícióját. A pedagógiajogi tanulmányokban elsősorban a közigazgatáshoz kapcsolódó szakigazgatás kifejezés oktatási területen használt megfelelője, s egyaránt utal az oktatás irányításában részt vevő intézményekre és a rájuk vonatkozó szabályokra, eljárásokra. Ez a megközelítés kevésbé veszi figyelembe, hogy az oktatás irányítása (mint ahogy más szakágazatoké is) nemcsak jogi kérdés, nemcsak az adott szakpolitika adminisztratív lenyomata, hanem társadalmi, gazdasági vetülete is van. Mivel rendelkezik bizonyos mértékű autonómiával, az eltérő környezeti feltételek (érdekek, hatalmi viszonyok) képesek a szakpolitikát (esetünkben az oktatáspolitikát) elmozdítani eredeti célkitűzéseitől, s összességében vagy részleteiben módosítani annak eredményességét. A szociológiai megközelítésű szakirodalom, mindenekelőtt az oktatástörténeti írások éppen ezért a tanügyigazgatásnak egy szélesebb, a politikai-társadalmi kontextust is magában foglaló megközelítését képviselik. ${ }^{1} \mathrm{Ez}$ utóbbit a tanügyirányitás (vagy másképp: oktatásirányítás) kifejezés is lefedi, amely a tanügyigazgatásnál kevésbé archaikus, s magában foglalja a szakpolitikának alárendelt teljes döntéshozatali rendszert, beleértve a különböző stakeholderek érdekérvényesítő tevékenységének rendszerét. $\mathrm{A} z$ angol szóhasználatra (education governance) is általában ez a szélesebb értelmezés a jellemző, de találkozni olyan uniós dokumentummal is (European ideas 2018), ami egybemossa a fogalmat az oktatáspolitikával (education policy). A szük értelemben vett tanügyigazgatásnak pedig leginkább az educational administration kifejezés feleltethető meg.

$\mathrm{A} z$ Európai Unión belül az oktatáspolitika és így az oktatásirányítás rendszerének kialakítása nemzeti hatáskör, ugyanakkor az Európai Unió Tanácsa az oktatást érintő közös célok teljesítése érdekében figyelemmel kíséri az egyes államok oktatását érintő folyamatokat, intézkedéseket, s ha szükségesnek látja, akkor az egyes kormányok számára évente megfogalmazott ajánlásai között oktatással kapcsolatos problémákra, veszélyekre is felhívja a figyelmet. Elsősorban az uniós célok teljesítésére fókuszálnak, azok teljesíthetőségét vizsgálják. A 2012. évi országjelentés például az oktatás irányítási rendszerének tervezett átalakításával kapcsolatban olyan konkrét veszélyeket jelez, mint a korai iskolaelhagyók számának emelkedése és a szegregáció növekedése (Council recommendation 2013). Ezek - föként a szegregációval kapcsolatos megállapítás - közvetlenül érintik az oktatás struktúráját és irányítási rendszerét is.

Az iskolák 2013-as államosítása a korábbi rendszer teljes átalakításához vezetett, ami sok feszültség okozója is lett. Az Educatio 2013/1. számában több tanulmány is foglalkozott ennek történeti elözményeivel, társadalmi-politikai vonatkozásaival. E tanulmányok

\footnotetext{
Lásd például Nagy Péter Tibor és Kelemen Elemér írásait.
} 
nagyjából a hogyan jutottunk ide és a miként értelmezzük a változásokat kérdésekre füzhetők fel. Az azóta eltelt bő fél évtized tapasztalatai már lehetővé tesznek más megközelítést. Tanulmányunkban egyrészt arra a kérdésre igyekszünk válaszolni, hogy a kormányzati célok mennyire voltak összhangban az uniós elvárásokkal, illetve hogy az új irányítási rendszer mennyiben, s mely elemeiben segítette, illetve gátolta a kormányzat oktatáspolitikai törekvéseit.

\section{$\mathrm{A} z$ állami beavatkozás új rendszerének indokai}

A rendszerváltás - a korábbi szocialista országokhoz hasonlóan - a decentralizált oktatásirányításra való áttérést jelentette. Bár az ezt követő két évtized oktatásirányítása nem volt változatlan, de jellemzően a központi (állami) koncepcionális irányítás és a helyi fenntartás egyensúlyára épült. Az állam irányító szerepét pénzügyi (normatívák) és szakmai eszközök (NAT, kerettantervek, tankönyvjóváhagyási rendszer, továbbtanulás szabályozása stb.) segítették. Ezek kívánták a rendszer autonóm, tehát a kormányzattól politikailag és szervezetileg is független szereplőit, vagyis az oktatási intézmények fenntartóit, s magukat az oktatási intézményeket is a kormányzat által elvárt irányba terelni. Ez az irányítási rendszer lehetővé tette azt is, hogy az oktatásra vonatkozó uniós célkitüzések megvalósítására késztesse az intézményeket. Lényegét tekintve illeszkedett más európai országok gyakorlatához is, amely - országonként ugyan jelentősen eltérő módon, de - szintén a kormányzati és a „helyi” szintű irányítás egyensúlyára épül, még ha ezek a szintek országonként mást és mást jelentenek is ${ }^{2}$, $\mathrm{s}$ a döntési jogkörök is jelentősen eltérhetnek egymástól. A kontinentális oktatási rendszerrel rendelkező országokban például nagyobb hangsúlyt kapnak a folyamatszabályozás bizonyos elemei (pl. tantervek, tankönyvjóváhagyási rendszer), míg az angolszász oktatási rendszerrel jellemezhető országokban erősebb a kimenetszabályozás (vizsgák, tudásfelmérések) szerepe.

A hazai oktatás a rendszerváltás utáni időszakban sok, részben folyamatosan jelenlévő problémával küzdött, sok területen az állam nem vagy alig volt képes az általa elgondolt irányba befolyásolni a rendszert, ugyanakkor megfigyelhető előrelépés is. Mint azt az időszak második évtizedét értékelő kötet egyik tanulmánya megállapítja: „...a modernizációs törekvések folyamatosan érvényesültek, és stabilan fennmaradtak az olyan oktatáspolitikai prioritások is, mint a minőség és az eredményesség vagy a méltányosság és az esélyegyenlöség biztositása. Ugyanakkor a változások irányában kisebb-nagyobb módosulások is láthatóak, például a fejlesztési célok elkerülhetetlen hozzáigazitása az uniós célokhoz" (Halász 2011: 21). Mindezek alapján egy Unió-konform oktatáspolitika és ehhez igazodó oktatásirányítási rendszer meghonosodásáról beszélhetünk, még ha a központi oktatásirányítás gyenge és kapkodó is volt, $\mathrm{s}$ a települési és az iskolai érdekek gyakran negligálták a központi elképzeléseket (Györgyi 2011).

A szakpolitikai beavatkozások céljait nem könnyủ megtalálni. Egyrészt azért, mert ezek összetettek, a különböző politikusok gyakran eltérő célokat fogalmaznak meg, s ezek időben is változhatnak, másrészt azért, mert a publikált célok politikai termékek, amelyek valamilyen politikai törekvés közvéleménnyel való elfogadhatóságát is szolgálják,

2 Szegmentáltabb politikai berendezkedésű országok esetében az „állami” szintet részben (például Németország, Spanyolország) vagy teljesen (Nagy-Britannia) esetében valamilyen alacsonyabb politikai egység képviselheti. A belyi szint alatt pedig a legkülönbözőbb nagyságú településeket vagy azok kisebb nagyobb egységét (járás, municipalitás) értjük. 
s ezért nem feltétlenül esnek egybe a tényleges politikai szándékokkal. Tanulmányunkban a nyilvánosságot kapott célkitűzésekből indulunk ki, s az összegzés során térünk ki arra, hogy ezek közül melyek indokolták az irányítás megvalósult rendszerét.

A 2010-ben alakult kormány programjaként felfogható Széll Kálmán Terv csak érintőlegesen foglalkozott az oktatással. Explicit módon nem mondta ki, de jelezte az irányt: „az államnak vissza kell térnie az oktatás világába. Nem függhet az oktatás színvonala az önkormányzatok helyzetétöl és eseti döntéseitöl, az állam ezen a téren egységes rendet tud tenni" (Széll Kálmán Terv [2011]: 23). Uniós kontextusba helyezve az állítást, azt látjuk, hogy egyrészt igazodik az Unió dokumentumaiban gyakorta megfogalmazott elvárásokhoz, így például az Oktatás és képzés 2020 (A Tanács következtetései 2009) dokumentumban deklarált négy általános cél egyikéhez, amely az oktatás minőségének (és emellett hatékonyságának) javítását célozza. Másrészt viszont ellentmondani látszik az uniós országok oktatásirányítási gyakorlatának, s egyoldalúan az állam szerepének erősítését szorgalmazza. Az államnak az oktatás világába történő „visszatérését” ugyanakkor még többféle módon lehetett értelmezni, nem volt feltétlenül szükségszerű eleme a későbbi államosítás. Már csak azért sem, mert ugyanez a terv a közigazgatásban éppen a bürokrácia csökkentésére helyezte a hangsúlyt („a közigazgatásban tovább csökkentjük a bürokráciát, mert a szükségesnél nagyobb bürokrácia mind lassúságával, mind a költségeivel növeli az államadósságot" [i. m. 33. o.]), márpedig a nagyobb szervezetek általában bürokratikusabban müködnek.

Hogy a kormányzati oktatáspolitikusoknak még nem volt ebben a tekintetben kiforrott, de legalábbis egységes álláspontjuk, arra az is utal, hogy még a köznevelési törvény későbbi koncepciója sem a később megvalósult fenntartói rendszerben gondolkodott. Ez a dokumentum (A Nemzeti köznevelésröl 2011) részletes támpontul szolgál az átalakítás céljait illetően, tizenegy pontban foglalva össze ezeket. E pontok részben a korábbi rendszer kritikái, s ezen keresztül jelölnek ki irányváltást, részben pedig explicit módon fogalmaznak meg elképzeléseket. Tartalmuk szerint három csoportba sorolhatók (i. m. 6-7. o.). A politikai-ideológiai típusú megfontolások elvi-politikai síkon kritizálják a korábbi oktatásirányítási rendszert, s inkább értékválasztást jelenítenek meg, mintsem szakpolitikai problémákat. Négy tétel sorolható ide:

- A korábbi szakpolitika a köznevelési rendszert piacként értelmezte, s ezzel kiszolgáltatta azt a nemzet felemelkedése iránt közömbös érdekeknek;

- Az értékalapú nevelést felváltotta az értékrelativizmus;

- A pedagógushivatás tekintélyvesztése mélyponton van; Megszünt az egységes nemzeti műveltség továbbadását szolgáló tartalmi szabályozás.

Politikai tartalmuk, értékválasztásuk miatt ezek valóságalapját, s a beavatkozásokat alátámasztó jellegüket most nem vizsgáljuk, de a tanulmány végén visszatérünk a témára.

A dokumentum az oktatás eredményességére vonatkozóan két problémát említ (az eredményesség általános romlása, illetve a felzárkóztatási programok sikertelensége és a tehetséggondozás szervesülésének hiánya), amelyek valós, több évtizede megoldatlan kérdéseket vetnek fel, s amelyek tényleges müködési zavarokra utalnak. A gyenge ta- 
nulói teljesítményeket a PISA-vizsgálatok visszaigazolják, ${ }^{3}$ mint ahogyan azt is, hogy a hátrányos helyzetűek leszakadása tekintetében a korábbi beavatkozások és támogatott programok ellenére átfogó változás nem történt. Ugyanakkor az ezredforduló utáni évtizedben mind olvasás-szövegértésben mind matematikában érzékelhető volt némi előrelépés, ${ }^{4}$ vagyis az általános romlás megállapítás nem helytálló. A leggyengébb (2-es szint alatt teljesítő) tanulók aránya is jelentősen csökkent, vagyis a felzárkóztatás kudarca így inkább csak az elvárások tükrében igazolható. A kritika tehetséggondozásra vonatkozó eleme nehezebben értelmezhető, s politikai nézőponttól függően vonatkoztatható a hátrányos helyzetűekre, a kiemelkedő tehetségekre vagy pedig a közoktatási rendszer valamely szintjén mért, kiemelkedő teljesítményt nyújtó tanulókra. (A megfogalmazásból, a későbbi kormányzati beavatkozásokból, illetve ezek hiányából ítélve a harmadik megközelítés látszik relevánsnak.) A törvényi koncepció a megállapítások alapján célként jelöli ki a leszakadó területek és társadalmi csoportok „minőségi oktatásba" való visszavezetését, ami a kompetenciamérési adatok (Országos kompetenciamérés 2009), illetve az erre épülő kutatások (lásd például Kertesi-Kézdi 2009) alapján valóban fontos feladat, s egyben igazodik is az Unió 2020-ra előirányzott egyik célkitűzéséhez (méltányosság) és a dokumentumban megfogalmazott, a lemorzsolódók arányának $10 \%$ alatti célértékéhez.

$\mathrm{Az}$ irányítást-finanszírozást öt pont érinti. A témakör közvetlenül nem köthető az oktatással kapcsolatos uniós célkitűzésekhez, de az irányítás hatékonyságának javítása összefüggésbe hozható az oktatás hatékonyságával is. A közigazgatás hatékonyságának javítását egyébként az Unió 2014-2020-ra szóló prioritásai között is megtaláljuk, ami alapján intézményi fejlesztések támogatását helyezték előtérbe, hogy ezek révén „stabilan és kiszámithatóan müködö intézmények jöjjenek létre, amelyek egyúttal kellöen rugalmasak abhoz, hogy válaszokat adjanak a társadalmi kibívásokra, nyitottak legyenek a nyilvánossággal való párbeszédre, új politikai megoldásokat mutassanak be, és hatékonyabb szolgáltatásokat nyújtsanak". ${ }^{5}$ A cél mögött nem nehéz észrevenni a közigazgatás megújítására vonatkozó, több évtizeddel ezelőtt megfogalmazott new public management szemlélet hatását. Külön az oktatásra vonatkozóan ez a hatékonysági elvárás nem jelenik meg, de mint közfeladat, ez is beleérthető. A köznevelési törvény koncepciójának idevonatozó öt pontjával, az ezekben szereplő állításokkal, s főleg azok sommás jellegével, illetve egyik-másik tényleges jelentőségével nem feltétlenül értünk egyet, de alapjuk sok tekintetben valós volt.

Az egyik általános kritika, hogy tisztázatlan és nehezen érvényesithetö az állam felelössége és irányitó szerepe (1). Az önkormányzatok a rendszerváltás utáni időszakban komoly szakpolitikai szerephez jutottak, aminek elvi alapját az, a közoktatási törvényben ki nem mondott, de abban erőteljesen érvényesülő alapelv jelentette, miszerint az oktatásnak az állam által meghatározott alapkövetelmények figyelembevételével - igazodnia kell a helyi igényekhez (és lehetőségekhez). A helyi oktatáspolitikák korlátait részben a tör-

3 Bár ezek megítélése is vitatható, sőt időnként vitatott is, s más vizsgálatok némileg más eredményekre jutnak, a PISA-eredmények mind Magyarországon, mind sok más országban oktatáspolitikai beavatkozások hivatkozási alapját jelentik, vagyis iránymutató jellegük megkérdőjelezhetetlennek látszik.

4 Olvasás-szövegértésben a mindkét felmérésben részt vevő 25 európai ország rangsorában az átlagpontokat tekintve Magyarország 2000-ben a 18., 2009-ben a 13., matematikából pedig 24 ország között 2003-ban a 18., az évtized végén pedig a 15. volt (Literacy Skills é. n.; First Results é. n.; Literacy Skills 2000).

5 https://ec.europa.eu/regional_policy/hu/policy/themes/better-public-administration/ [Letöltve: 2019. 06. 16.] 
vényben az államra ruházott jogok jelentették, részben pedig a pénzügyi támogatások adott - az adott időszakban detektált vagy deklarált problémák megoldását elősegítendő - szisztémája. Ebben a rendszerben valóban voltak tisztázatlan elemek - például, hogy az állam meddig csorbíthatja intézkedéseivel a fenntartói jogokat -, ugyanakkor a gyenge irányítói szerep csak részben volt visszavezethető ezekre, sokkal inkább az átgondolatlan, következetlen, s gyakran változó szabályozási elemekre.

Egy decentralizált rendszer magában hordozza annak lehetőségét, hogy az országosan (a mindenkori kormányzat által) képviselt szakpolitika és az önkormányzati fenntartók által képviselt „helyi” szakpolitikák - akár elvi-politikai, akár praktikus (szabályozási, finanszírozási) megfontolások mentén - nem azonos irányt képviselnek. Ennek nyoma rendre kitapintható volt a 2010 előtti időszakban. Olyannyira, hogy a fenntartói döntések nem egy esetben már nemcsak helyi szinten, hanem összességében, vagyis országosan is akadályozták a kormányzati célok megvalósulását.

$\mathrm{A} z$ általános iskolai képzésben különös jelentőséget adott mindennek, hogy a szétaprózott rendszer kevésbé volt képes megbirkózni a települési szegregációból (is) eredő iskolai szegregációval, sőt erősítette is azt. Ráadásul a fejlesztési lehetőségek hiánya leginkább a gyenge anyagi helyzetü fenntartók hátrányos helyzetüeket koncentráltan oktató iskoláit érintette (Hermann-Varga 2011).

$\mathrm{A} z$ „állam” (vagyis a kormányzat) felismerte saját felelősségét az oktatás irányítása tekintetében, de az alkalmazott eszközök gyengék, s éppen ezért hatástalanok maradtak. Jellemzően nem vették figyelembe azokat az önkormányzati (és az ezek mögött álló társadalmi) érdekeket, ezek történelmi gyökereit, illetve az iskolák településeket érintő szimbolikus erejét, amelyek akadályozták egy racionálisabb iskolaszerkezet kialakítását. Ezért maradtak fenn változatlan formában a kistelepülési kis iskolák, s ilyen okok következtében nem jelentett érdemi előrelépést a térségi integrált szakképző központok rendszere sem. Ugyanerre volt visszavezethető az is, hogy minden országos törekvés ellenére alig csökkent az iskolai szegregáció, amelyet a fenntartók legfeljebb látszatintézkedésekkel igyekeztek elfedni, ${ }^{6}$ miközben tényleges szegregációcsökkentő intézkedésekre csak néhány városban került sor (Szücs 2013).

Mindez megalapozta a törvényi koncepcióban szereplő másik kritikai elemet, miszerint az oktatásra egyaránt jellemző a hiánygazdálkodás és a túlköltekezés (2). Az utóbbit intézményi szinten ugyan akadályozta az önkormányzati saját források kiemelkedő szerepe és így a pazarlás megszüntetésében való érdekeltségük, de a pazarlóan müködő iskolahálózat - föként az alapfokú oktatásban és a szakképzésben - összességében mégis túlköltekezéshez vezetett, ami az igények oldaláról nézve hiánygazdálkodásként is értelmezhető, mert a müködési kiadások - egyebek mellett - a fejlesztésektől vontak el forrásokat.

A z évtized végén (majd a kormányváltás utáni években is) az alapvető financiális problémák (forráshiány, s az ebből eredő fizetési nehézségek) ugyanakkor nemcsak a gyenge forrásfelhasználásból eredtek, hanem sokkal inkább az önkormányzatok alulfinanszírozottságából, amit az önhibájukon kívül hátrányos helyzetű települések magas száma, illetve az ennek feltételéül szabott racionális intézményfenntartást megkövetelö elvárások egyértelmüen jeleznek (Györgyi 2011).

\footnotetext{
Az egyik megyeszékhelyen mind a nyolc általános iskolát egy szervezetbe vonták össze, így a szegregáció legfeljebb feladatellátási hely szinten volt kitapintható (Szöke 2011).
} 
A törvényi koncepció kifogásolta az oktatásirányítás gyakorlatát is, miszerint az aprólékos túlszabályozottság átláthatatlan müködést, önállótlanságot, merevséget eredményez (3). Pénzügyi területen valóban érzékelhető volt túlszabályozottság (Szabó-Fehérvári 2013), de más tekintetben aligha, s a pénzügyi szabályozás is inkább alkalmazkodást, vagyis rugalmasságot igényelt a fenntartóktól, az iskoláktól, még ha ez sok esetben nem a kormányzati célkitűzések irányába mutatott is, hanem azzal ellentétes megoldásokat eredményezett. Az iskolai innovációk korlátját sem annyira az irányítási rendszerben, mint inkább a pénzügyi korlátok mentén kell keresni, de különböző támogatási források álltak ehhez rendelkezésre, így inkább innovatívnak nevezhető a rendszer (Fazekas-HalászHorváth 2018), bár kétségtelen, hogy mindez nehezen volt átlátható.

A koncepció szerint az intézményi döntésekben laikusok kaptak meghatározó szerepet a pedagógiai megfontolásokkal szemben (4). Tény, hogy az oktatásirányítás hármas döntéshozatali rendszerében - országos, fenntartói, intézményi - „laikusok” is részt vettek, ami a rendszer lényegi eleme volt. Az irányításban való társadalmi részvétel törvényszerü, miután a legfontosabb oktatási jogszabályokat is az oktatás szempontjából nézve "laikus" törvényhozó testületek hozzák. A laikusok intézményi szintről való visszaszorítása tehát nem annyira az ő visszaszorításukat célozhatta, mint inkább a helyi szintét. Bár ebben a tekintetben sincs egységes európai gyakorlat, de az iskolafenntartás jellemzően valamilyen kisebb területi egység önkormányzatához, vagy iskolafenntartó testületekhez köthetö, kifejezve azt, hogy vannak legitim helyi érdekek, amelyek érvényre juttatása hozzájárul az oktatás eredményességéhez, ${ }^{7}$ illetve hogy ezek fentről nem láthatók, éppen ezért nehezen kielégíthetők. Az ezekkel kapcsolatos döntések nyilván nem nélkülözik a szakmai hátteret, a szakmai érdekek megjelenítését. A hazai önkormányzatok - részben elaprózottságuk okán - gyakran valóban nem rendelkeztek megfelelő szakmai háttérrel, de az is igaz, hogy a szakmai háttér sem feltétlenül eredményez szakmailag megalapozott döntést, tekintettel arra, hogy a döntések jelentős része politikai döntés abban az értelemben, hogy bizonyos rétegérdekeket előtérbe, másokat pedig háttérbe helyez. Mindennek fényében a kritika nehezen értelmezhető, sokkal inkább a kormányzati és az önkormányzati döntések közötti diszkrepanciára vonatkozható.

Végül az utolsó, irányítási-finanszírozási jellegű megállapítás a külső szakmai kontroll biányát (5) jelezte problémaként. Bár ebben a tekintetben is volt felépített rendszer 2010 előtt, de az valóban a belső, illetve a (sok esetben valóban „laikus”) fenntartói kontrollra épült. Átfogó pedagógusminősítési rendszer nem működött, de talán még inkább hiányzott az intézményi munkát átfogóan minősítő s árnyalt visszacsatolást lehetővé tevő rendszer, még ha egy-egy nagyobb településen ki is dolgoztak ilyet.

Mindez összességében részben arra utal, hogy az oktatási rendszer egyes aktoraihoz hozzárendelt döntési jogok nem voltak minden tekintetben jól leosztva, részben pedig arra, hogy a fenntartói döntéshozókat befolyásoló - főként pénzügyi - szabályozók egyes

Az Educational at a Glance kiadvány rendszeresen közöl adatokat arra vonatkozóan, hogy az oktatást érintő különböző operatív jellegű döntések milyen szinten (országos/regionális, helyi, illetve iskolai) szinten születnek. A helyi és az iskolai szintű döntések, legyenek azok szakmai vagy laikus kezekben, mégis inkább a helyi érdekek megtestesítői, különösen annak figyelembevételével, hogy a pedagógusok foglalkoztatói jellemzően helyi - tehát az államtól független - szervek, testületek. Anélkül, hogy az adatok pontos értelmezésébe belemennénk, vagy akár túlzott jelentőséget tulajdonítanánk ezeknek, segítheti a tájékozódást, hogy 2011-es adatok alapján a (felmért) döntések 31 ország közül 17-ben teljes mértékben ezen a szinten születtek, s ezek között jellemzően 20-40 százalék volt a helyi, tehát leginkább települési szintű döntések aránya. 
elemei nem múködtek hatékonyan, nem vették figyelembe a helyi érdekeket. Éppen ezért a kormányzati elképzelések helyi szinten gyakran megfeneklettek. Az arra rászorult fenntartók szakmai és pénzügyi segítséget alig kaptak, ez pedig az intézményrendszer szétszakadását eredményezte.

\section{Az államosítás első évei}

A fenti problémákból s a problémákhoz hozzárendelt célkitűzésekből nem vezethető le közvetlenül az iskolák fenntartói, s így az oktatással kapcsolatos irányítási rendszerének 2013-ban megvalósult teljes átalakítása. A kormányzati oktatáspolitika is csak később jutott el ehhez a változathoz. Eredetileg - s ezt tükrözi a törvényi koncepció - a 2000 főnél népesebb települések - a szakiskolák kivételével, s bizonyos feltételek esetén ${ }^{8}$ megtarthatták volna iskolafenntartói jogukat. A teljes körü állami kézbevételről csak később született döntés, mégpedig a részleteket tekintve nem teljesen átgondoltan. Erre utal, hogy az ún. működtetésről az addig iskolafenntartó önkormányzatoknak rövid idő alatt kellett dönteni, s döntéseikben nem támaszkodhattak már kidolgozott pénzügyi szabályozásra (Kardos-Kovács 2015).

$\mathrm{A} z$ irányítási rendszer átalakítása során a legfontosabb döntési jogok fenntartóról fenntartóra szálltak, vagyis az önkormányzatoktól az államhoz kerültek. Ez azt is jelenti, hogy a korábban háromszintű irányítási rendszer - kis korlátozással - kétszintűvé, bár többszereplőssé változott. Az új rendszerben iskolák alapításáról és megszüntetéséről már nem dönthetett az önkormányzat, s az államhoz került a pénzügyi források elosztása, valamint az iskolai pedagógiai programok költségvetést érintő tételeinek elfogadása. A pedagógiai programok egyéb tekintetben iskolai hatáskörbe kerültek ugyan, ami szakmai önállóságuk formális (és deklarált) meghagyását, sőt megerősítését jelentette, ugyanakkor magában hordozta az erőteljes korlátozás lehetőségét is, mivel a szakmai tevékenységnek sokféle anyagi vonzata lehet, s miután az iskolák vezetői, sőt a pedagógusai is egy hierarchikusan felépített rendszer alsó szintjének szereplői lettek. A legátfogóbb beavatkozás éppen a foglalkoztatás területén történt, ahol nemcsak az igazgatók kinevezésének joga szállt át fenntartóról fenntartóra, hanem az iskoláknak a pedagógusok foglalkoztatásáról is le kellett mondaniuk. Az iskolákon kívül ugyancsak az államhoz kerültek a korábbi pedagógiai szolgáltató központok, s ezzel nemcsak a pedagógiai szakszolgálatok, hanem a szakmai tanácsadás is. Az önkormányzatok mindössze az ún. müködtetési feladatokat tarthatták meg, ami valójában csak tehervállalást jelentett számukra, irányítási jogot semmilyen formában nem. Új szereplőként jelentek meg az irányításban a kormányhivatalok, amelyek a beiskolázási körzeteket határozhatták meg. Ezzel egy komoly szakpolitikai beavatkozási lehetőség kikerült az oktatási tárca felügyelete alól.

Ha végignézzük a törvényi koncepcióban megfogalmazott, az irányítással-finanszírozással kapcsolatos öt célkitűzést, akkor az első három év azt jelzi, hogy ezeket államosítás nélkül is meg lehetett volna valósítani, pusztán a döntési jogkörök kisebb átalakításával, a müködést érintő elvárások pontosításával és azok szigorú betartatásával. Eredmény a centralizált irányításra történő áttéréssel ugyanakkor egyáltalán nem mutatkozott meg, viszont nagyon gyorsan kiütköztek a hátrányai, nem egy esetben éppen

Amennyiben az önkormányzat szerződést köt az állammal, s vállalja, hogy a megyei közoktatási fejlesztési terv szerint tartja fenn az iskoláit. 
a megfogalmazott célokkal ellentétben (Györgyi 2015). Az állami felelősségvállalás valóban nagyobb lett, de a kormány egy hatalmas bürokratikus irányító szervezetet hozott létre ehhez, amelynek müködése még számára is átláthatatlanná és kezelhetetlenné vált.

$\mathrm{A} z$ irányítási rendszer átalakítása jelentős forráskivonással párosult. ${ }^{9}$ Feltételezhetően ebben szerepük volt az állami költségvetés hiányát visszaszorítani kívánó törekvéseknek, de annak is, hogy a centralizált irányítástól a kormány megtakarítást várt. Mivel azonban rosszul mérték fel az oktatási rendszer müködésének tényleges költségeit, ${ }^{10}$ így a forráskivonás finanszírozási nehézségekhez vezetett. Miután a rendszerben dolgozók béreihez nem lehetett nyúlni, ezért vagy a béren felüli juttatásokat kellett csökkenteni, vagy strukturális beavatkozásokat megvalósítani, vagy pedig más területek kiadásait visszafogni. Az előbbi kettő olyan beavatkozásokat igényelt volna (intézmények összevonása, pedagógiai programok módosítása, egységes béren kívüli juttatások ${ }^{11}$ ), amelyeket a kormányzat - a legkülönbözőbb politikai okokra visszavezethetően - nem vállalt fel. Ez vezetett aztán a létszámstophoz, illetve a dologi s a túlmunkához kapcsolódó bérkiadásokkal kapcsolatos megszorításokhoz. Vagyis a teljes költségvetés kis szeletén kellett a jelentős költségcsökkentést elérni, ami végül a pénzügyi múködés ellehetetlenüléséhez és müködési zavarokhoz vezetett. Az új irányítási rendszernek pénzügyi vonalon egyetlen előnye volt csak kitapintható: az alapbérek késlekedés nélkül érkeztek meg, ami a szegényebb (vagy inkábbः elszegényített) önkormányzatok korábbi intézményeinél javította a pedagógusok biztonságérzetét, legitimálva körükben az államosítást. A hiánygazdálkodás tehát a bérek tekintetében megszünt, de minden más területen újabb hiányok keletkeztek, ennek megfelelően a célul kitűzött állami felelősségvállalás inkább felelötlenséget eredményezett.

A korábban túlszabályozottnak tekintett normatívarendszer az állami oktatásban megszünt. A finanszírozás ezzel viszont belső intézményi üggyé, vagyis láthatatlanná vált: nemcsak az iskoláknak, de a tankerületeknek sem volt önálló költségvetésük, s ezzel kapcsolatos döntési jogkörük sem. A belső elosztási rendszerről nem sokat lehetett tudni, az ezzel kapcsolatos kutatást is meghiúsította a KLIK. Lényegileg feladatfinanszírozásra álltak át, ami a fóbb tételek tekintetében az addigi helyzetet konzerválta, egyéb esetekben pedig kézi vezérléssel történt. A korábbi rendszert tehát egy túlbürokratizált, s éppen ezért müködésképtelen alternatíva váltotta fel, ami - a megfogalmazott célokkal ellentétben - mindenféle önállóságot elnyomott, s a korábbinál sokkal merevebb rendszert eredményezett.

Ez a pénzügyi rendszer, mivel nem voltak kitapintható koncepciók, forrásokat allokáló szabályok, alkalmatlan volt az iskolák közötti különbségek csökkentésére is, amit akadályozott az is, hogy a müködési költségek - részben - továbbra is az eltérő anyagi

9 A forráskivonás már 2011-ben megkezdődött, s 2013-ig tartott. 2010-ben az alap- és a középfokú oktatás állami és önkormányzati forrásból kifizetett költsége 685 milliárd forint volt, 2012-ben $621 \mathrm{Mrd}$, a következő évben pedig már csak $586 \mathrm{Mrd}$. Ezt követően - éppen a hiányproblémák miatt - rohamosan emelkedni kezdett, s 2016-ra (utolsó adat) elérte a 839 Mrd Ft-ot. Forrás: KSH-Stadat.

10 Az önkormányzatok sok olyan tevékenységet finanszíroztak az oktatásban, amelyeknek fedezete nem jelent meg az iskolai költségvetésekben, nem beszélve arról, hogy bizonyos feladatok önkormányzati erőforrásokat alkalmazva olcsóbban elláthatók, mint egy távoli fenntartó által adott megbízás keretében.

11 A pedagógiai programok felülvizsgálata ugyan megtörtént 2013-ban, de ez inkább csak adminisztratív jellegü intézkedés volt. 
helyzetü önkormányzatok kezében maradtak, s éppen a legszegényebbek adták át azokat az erősen forráshiányos állami fenntartó szervezetnek.

$\mathrm{A} z$ új irányítási rendszer valóban háttérbe szorította a „laikusok”, mindenekelőtt az önkormányzatok szerepét, ugyanakkor nem látszott erősödni a szakembereké. A szakértői döntéseknek kevés terepük maradt a már említett pénzügyi nehézségek miatt. A döntési rendszer az egyetlen állami irányító ellenére a korábbinál is átláthatatlanabbá vált (a normatívarendszer alapján legalább a kormányzati szándékok kitapinthatók voltak). Kutatási tapasztalatok (Györgyi 2015) azt jelzik, hogy szakmai alapon történő beavatkozások nem történtek a rendszerbe. Sem országosan, sem tankerületi szinten. Ez utóbbinak nemcsak a korlátozott pénzügyi lehetőségek szabtak határt, hanem a tankerületek kiszolgáltatottsága, s a napi ügyek miatti lekötöttségük is.

$\mathrm{A} z$ ellenőrzési rendszer új eleme a tanfelügyeleti rendszer ${ }^{12}$ bevezetése volt, ennek kialakítása megkezdődött. Alapja egy évről évre módosított, intézménytípusonként eltérő tartalmú kézikönyv, amely az ellenőrzés részletesen szabályozott forgatókönyvét és az ellenőrzés utóéletét szabályozta. ${ }^{13}$ Bár az ellenőrzések megállapításai nyomán intézményi szintű intézkedési terveknek kellett készülniük, de ezek fenntartókra háruló következményei nem képezték részét a rendszernek, vagyis a szükséges korrekciók csak intézményen belüli intézkedésekre, fenntartói döntésekre viszont csak esetlegesen támaszkodhattak. Magát a rendszert is sok kritika érte. ${ }^{14}$

\section{6: az irányítási rendszer korrekciója}

A tanügyirányítás 2013-ban kialakított rendszerének problémái hamar felszínre kerültek. Ezek jó részét az irányító minisztérium egy belső munkaanyagban tárta fel, de okait nem a rendszerjellemzőkben, hanem a fenntartó szervezet gyenge működésében látta. Korábbi kutatásaink nyomán több publikációban is rámutattunk arra, hogy a túlcentralizált, s egyébként is átgondolatlan és kidolgozatlan irányítási rendszer alapvetően volt alkalmatlan arra, hogy a fennálló problémákat kezelje. Korrekciójára végül a 2016 eleji kockásinges demonstrációk hatására került sor, a köznevelési törvény fél évvel későbbi módosítása (2016. évi LXXX. törvény) során.

A legelső - még a törvényi változások előtt - megtett intézkedések is visszaigazolták a rendszer működésére vonatkozó kritikai észrevételeket. Elsődlegesen a pénzügyi és adminisztratív okokra visszavezethető problémákat igyekezett az oktatási kormányzat kezelni, némi döntési lehetőséget biztosítva a tankerületi és az iskolai vezetőknek, csökkentve ezzel a bonyolult adminisztratív eljárásokat is. ${ }^{15} \mathrm{~A}$ pedagógusok megnyug-

12 Köznevelési törvény (2011. évi CXC. törvény) 78.§ (1) bekezdés f pontja.

13 Ezek az ún. tanfelügyeleti kézikönyvek: https://www.oktatas.hu/kiadvanyok/tanfelugyeleti_kezikonyvek. [Letöltve: 2019. 06. 16.]

14 A 2016. évi tanári demonstráció ezért is fogalmazta meg, hogy „A pedagógus életpályához kapcsolódó minősítés és a pedagógiai-szakmai ellenőrzés rendszerét azonnal fel kell függeszteni, a folyamatban levő eljárások befejezésének kivételével!” (https://oktatas.atlatszo.hu/2016/03/15/marcius-15-pedagogustuntetes-percrol-percre/). Nahalka (2017: 70) szerint a minősítési rendszer egyrészt „figyelmen kívül hagyja a szervezeti működés eredményességét és hatékonyságát”, másrészt ugyancsak „figyelmen kívül hagyja a létező - és jól müködő(!) - minőségirányítási rendszereket".

15 Köznevelési kerekasztal - több azonnali intézkedésről döntöttek. https://www.kormany.hu/hu/emberieroforrasok-miniszteriuma/hirek/koznevelesi-kerekasztal-tobb-azonnali-intezkedesrol-dontottek. [Letöltve: 2019.06 .12 .] 
tatását szolgálta a bejelentett béremelés, s kilátásba helyezték a tanfelügyeleti rendszer egyszerűsítését is. A tervezett további intézkedéseket egy „oktatási kerekasztal” keretében, s ennek munkacsoportjaiban vitatták meg. Hogy ezek a kerekasztal-megbeszélések mennyiben járultak hozzá a későbbi változásokhoz, nem lehet dokumentálni, mert a jegyzőkönyvek nyilvánosan nem hozzáférhetőek. A fórum mind a mai napig müködik (Köznevelés-stratégiai kerekasztal néven), sőt valamelyest intézményesült is - 1382/2017. (VI. 16.) Korm. határozat -, de a köznevelési törvényben nincs nevesítve, így az ott megfogalmazott ajánlások a törvényalkotók számára semmilyen kötelezettséggel nem járnak. Lényegében hasonló funkciót tölt be, mint az Országos Köznevelési Tanács, de valamivel szélesebb társadalmi bázison.

A 2016. évi törvénymódosítás végül több területen is módosította az irányítási rendszert. Legfőbb jellemzője, hogy lényegesen csökkentette az intézményfenntartói döntések koncentráltságát. Ehhez a korábbinál nagyobb tankerületeket hozott létre (198 helyett 58-at $\left.{ }^{16}\right)$, amelyek lényegesen önállóbban müködhettek elődeiknél. Ezek kapták meg az iskolák fenntartói jogát, saját költségvetésük lett, s a pedagógusok kinevezése is tankerületi hatáskörbe került. Ez utóbbiban - felterjesztőként - az iskolaigazgatók is szerephez jutottak. A tankerületek lettek az iskolaigazgatók foglalkoztatói, s hozzájuk került az ezt megelőzően még az önkormányzatok kezében maradt müködtetés, vagyis a nem pedagógiai feladatokat ellátó dolgozók foglalkoztatása és a tanítás tárgyi feltételeinek biztosítása. Az iskolaigazgatók kinevezése ugyanakkor továbbra is országos szinten történik, még ha a tankerületek ebben kezdeményező, a nevelőtestületek pedig a pályázatokat véleményező szerepet is kaptak. ${ }^{17} \mathrm{Az}$ irányítási rendszer tehát igyekezett elmozdulni alacsonyabb szint felé, ugyanakkor a tankerületek központtól való továbbra is erős függése (a központ feladata maradt vezetőik kinevezése, költségvetésük megállapítása) arra utal, hogy az oktatási kormányzat csak apróbb korrekciót hajtott végre a rendszeren, továbbra is erősen centralizált módon képzeli el az irányítást. Ezt jelzi a kialakított tankerületek viszonylag csekély, s ennek megfelelően az ezekhez tartozó iskolák magas száma is, ami inkább a tankerületek országos irányításának érdekeit szolgálja, mintsem a tankerületeken belüli hatékony irányításét. Nehéz ugyanis szakmai érvekkel alátámasztani az átlagosan ötven iskola egy tankerületbe való szervezését ${ }^{18}$. A centralizált müködést továbberősítette az önkormányzatok teljes kiszorítása az oktatásból.

A 2016. évi törvénymódosítás idején módosították a KLIK működését (azóta Klebelsberg Központ - KK - néven szerepel). Az ezt tartalmazó rendelet látszólag társadalmasítani igyekszik a tankerületek tevékenységét a tankerületi tanácsok felállításával - 134/2016. (VI. 10.) Korm. rendelet -, de egyrészt az ezzel kapcsolatos alsóbb szintü jogszabály - 308/2017. (X. 27.) Korm. rendelet - másfél évig váratott magára, másrészt úgy szabályozta ezek funkcióját, résztvevőit és müködési mechanizmusát, hogy egyértelmúsítette az állam vezető szerepét. Amellett, hogy ezek a testületek csak a tankerületek által előterjesztett témákban kaptak tanácskozási jogot, s tagjainak kormányhoz való (nem egy esetben függelmi) helyzete s társadalmi érdekeket képviselő szerepük alap-

16 Forrás: Edumap adatbázis: http://edumap.ofi.hu/hu/?id=0109de37981b56c6d18883e5b2ac7342/2014/ files. Azóta két újabb tankerületet alakítottak ki, így jelenlegi számuk 60.

17 E véleményezési jog visszavonása épp e tanulmány idején merült fel a törvény várható módosításának keretén belül.

18 A tankerületekhez tartozó általános iskolák száma létrehozásukkor 20 és 95 közötti, átlagosan 50 volt. (Azóta a legnagyobb tankerületet megbontották.) 
ján erősen szelektáltak ${ }^{19}$. Felállításuk és működésük kormányzati oldalról olyannyira körbebástyázott, hogy aligha valószínü, hogy alternatívákat fogalmazzanak meg a kormányzati szándékok kapcsán. A kormányzat tehát nemcsak az oktatás irányítását nem engedi ki kezéből, de még a tankerületi szintủ véleménynyilvánítást is erősen korlátozza.

A bevezetett változások az állam irányító szerepét semmilyen tekintetben nem gyengítették, sőt némileg erősítették is azt. Egyfajta adminisztratív korrekciónak tekinthetők, amely a müködőképesség javítását célozta, $\mathrm{s}$ - valamelyest - eredményezte is. Az érdemi döntéseket továbbra is állami intézmények hozzák meg, még ha bizonyos esetekben nem is a központ, hanem annak tankerületi egységei. Az utóbbiak önálló költségvetése nagyobb mozgásteret enged nekik, de nem látható, hogy ezt használhatják-e bármilyen érdemi döntésre. A rendszer müködése továbbra is zárt belső ügy, tankerületi koncepcióknak nincs nyoma. A források elosztása - sem elvei, sem gyakorlata - kívülről nem látható. Jól látható szabályozók hiánya könnyen vezethet a források „kijárásos alapon történő” allokálásához, ami viszont komoly, s nem könnyen átlátható egyenlőtlenségeket eredményez. Nem kizárt, hogy vannak ezt kiegyenlítő mechanizmusok az intézményen belül, de ennek publikus nyoma nincs. Nem látható a státuszok elosztásának gyakorlata, az igazgatók kiválasztásának elvei, a pedagógiai programokkal kapcsolatos álláspontok. A rendszer ugyan szakemberek kezében van, de elvesztett szinte minden társadalmi kontrollt.

\section{Konklúzió}

Ha a köznevelési törvény koncepciójában kijelölt, a korábbi irányítást és a finanszírozást bíráló tételekből indulunk ki, akkor egyrészt azt látjuk, hogy - bár van valóságtartalmuk, de nem mindenben állják meg a helyüket, másrészt az ezek alapján megfogalmazott irányokhoz nem is lett volna szükség az államosításra és ezzel kapcsolatban az irányítási rendszer teljes átalakítására. Enélkül is tisztázni lehetett volna az állami és az önkormányzati felelősségvállalás határait, szükség esetén a korábbihoz képest új konszenzusra jutva ezek tekintetében, és a szakmai ellenőrzés szigorításával lehetett volna a kormányzat által prioritásként kezelt irányokba eredményesen terelni az iskolákat, illetve az önkormányzati fenntartókat. A finanszírozási rendszert akár a korábbiaktól eltérő alapokra is lehetett volna helyezni, s olyan ellenőrzési és ezek alapján kidolgozott beavatkozási rendszert bevezetni, amely nemcsak iskolai szinten, hanem rendszerszinten is képes kezelni a problémákat, $\mathrm{s}$ a különböző tanulói rétegeket a számukra és a kormányzat számára is elfogadható tanulási pályára állítani. Nemzetközi tapasztalatok ugyan azt mutatják, hogy az oktatási rendszer eredményessége, vagy akár az eredmények szórása, nem függ a rendszer centralizáltságától, ${ }^{20}$ de az állítást akár meg is fordíthatjuk: a centralizált döntési mechanizmus sem feltétlenül járul hozzá az eredményességi mutatók javulásához, a tanulói vagy akár iskolai szintü különbségek csökkentéséhez. Ezt a hazai tapasztalatok egyértelműen alátámasztják.

A fent leírtak alapján az is kirajzolódik, hogy a megfogalmazott irányítási-finanszírozási jellegü célkitüzések egy része nem is valósult meg, ugyanakkor olyan újabb problé-

19 KK, Nemzeti Pedagógus Kar, diákönkormányzatok, Nagycsaládosok Országos Egyesülete, Nemzetiségi Önkormányzatok Országos Szövetsége, önkormányzati szövetségek.

20 Sáska (2013) és Györgyi (2016) tapasztalatai is azt jelzik, hogy európai szinten a decentralizáltabb döntési mechanizmussal rendelkező oktatási rendszerek ugyan mindkét tényezőt tekintve jobb helyzetben vannak, de egyrészt az összefüggés nem túl szoros, másrészt nem bizonyítható az ok-okozati kapcsolat. 
mák keletkeztek, amelyek akadályozták a rendszer eredményes müködését. Nem véletlen, hogy az uniós országjelentésekben folyamatos volt a magyar oktatási rendszer kritikája, mégpedig annak ugyanazon két megoldatlan problémája - a szegregáció és a korai iskolaelhagyás - mentén (A Tanács ajánlása 2019). Az utóbbiban némileg még romlott is a helyzet, ami teljességgel ellentétes az uniós országok többségében tapasztaltakkal. A jelentések folyamatosan figyelemmel kísérték nemcsak a már bekövetkezett folyamatokat, hanem az oktatásirányításban tervezett változások várható hatásait is, mint például a szakképzés átszervezését. Ezzel kapcsolatban a 2015-ös dokumentum már figyelmeztetett arra, hogy a tervezett intézkedések csökkentik a rendszer horizontális átjárhatóságát, ami különösen a hátrányos helyzetűek számára kedvezőtlen ( $A$ Tanács ajánlása 2015). A dokumentumok nagyon diszkréten kezelik az oktatás irányításának kérdését, ugyanakkor az a tény, hogy a magyar oktatási rendszerrel kapcsolatos megállapításaik egy évtizeden keresztül közel azonos problémákat jeleztek, arra utal, hogy egy fontos uniós célkitűzés háttérbe szorult. Annak ellenére, hogy az oktatási rendszer átszervezésekor, ha nem is hangsúlyosan, de még országon belül is hangsúlyt kapott. Eközben a másik, a törvényi koncepcióban megjelenő eredményességi mutató nemhogy javult volna, hanem még romlott is. $\mathrm{S}$ ugyanígy háttérbe szorult a nyilvánossággal való párbeszédre épülő oktatásirányításra vonatkozó, korábban említett uniós prioritás is.

Mindezek alapján feltételezhető, hogy az iskolák államosításának indokát nem a korábbi irányítási-finanszírozási problémák talaján kell keresni, hanem sokkal inkább a politikai-ideológiai célkitűzések között (értékalapú nevelés, egységes nemzeti műveltség ${ }^{21}$ ), s ezzel összefüggésben az oktatás tartalmi elemeinek gyökeres átrendeződésének szándékához igazodva, mégpedig úgy, hogy ez a lehető legkisebb ellenállással legyen megvalósítható. Erre utalnak a nemzeti alaptanterv átalakításával, a tankönyvi kínálat államosításával kapcsolatos szándékok, de ugyancsak ezt támasztja alá, hogy az állam 2016 után, vagyis amikor az előző irányítási szisztéma kudarcot vallott, sem engedett át semmilyen kulcspozíciót, sőt e tanulmány írásakor épp további kísérletet tesz erre a köznevelési törvény módosításával. De erre utal a centralizáció sajátos értelmezése is, vagyis az, hogy miközben az önkormányzati intézményeket államosította, egy részüket átengedte egyházi kézbe, vagyis épp ellentétes folyamatot segített. Mindez azt jelenti, hogy egy kettős iskolarendszer megerősödéséhez járult hozzá, amely ideológiai alapon egységes, ugyanakkor hozzájárult a szegregált oktatás fennmaradásához, sőt - bizonyos esetekben - a megerősödéséhez. ${ }^{22}$

Bár az európai országok oktatási s így irányítási rendszere nagyon eltérő, de jellemzően a különböző szintű döntések megosztására épül. Kimondva-kimondatlanul érvényesül ezen a szinten is az egyébként az uniós és a nemzeti döntési rendszerek viszonylatában

21 A másik két politikai-ideológiai célkitűzés közül a köznevelési piac visszaszorítása inkább csak a két jelzett cél megvalósításának eszköze, a pedagógushivatás tekintélyvesztése megszüntetésének pedig nincsenek is látható jelei. A pedagógus-életpálya modell ugyan megvalósult, de egyrészt sokan megkérdőjelezik ennek alapját, másrészt a pedagógusbérek karbantartása elmaradt, így a versenyszféra bérei ismét relatív bércsökkenést jelentenek az oktatás területén. A felsőoktatásban ugyan megnőtt a pedagógusnak tanulók száma, de ez a képzés átszervezésének és a pedagógusszakokra való viszonylag könnyű bejutásnak a következménye.

22 Az egyházi iskolákat általában az iskolázottabb szülői rétegek preferálják (Palotás-Jankó 2011), így ahol az egyházi iskola az állami iskola alternatívája, s nem kifejezetten a hátrányos helyzetűekre koncentrálnak, ott még akkor is elindul a spontán szegregáció, ha az egyházi iskola vezetésének nem is volt ilyen szándéka. Ugyanez a folyamat a magániskolák esetében is lejátszódhat. 
érvényesülő szubszidiaritás elve, vagyis az, hogy a döntéseket a lehető legalacsonyabb szinten kell meghozni. Ennek ugyan sokféle értelmezése lehet, részben ez okozza az oktatási rendszerek sokszínűségét, de alapvetően arra utal, hogy az állam (vagy más erőközpont) nem képes nagy rendszereket közvetlen módon hatékonyan irányítani. A hazai rendszer nem számol ezzel a tapasztalattal, mint ahogy azzal sem, hogy a legtöbb európai országban az irányítás a különböző szintű döntések kifinomult egyensúlyára épül. A mi erősen centralizált rendszerünk ugyanakkor a központ (KK, tankerületek) és a központtól financiálisan és egzisztenciálisan függő intézményi aktorok döntésének „egyensúlyára” épül, ami szükségszerüen vezet a központi döntések dominanciájához és a helyi kezdeményezések és így a helyi igényekhez való alkalmazkodás megnehezítéséhez. Az oktatás, s ezen belül a hátrányos helyzetüek oktatásának eredményessége pedig nem csupán egy importált, de számunkra idegen cél: egyrészt a jövő alulképzett s munkát nem találó rétegeinek eltartása a társadalom dolgozóira hárul, másrészt a gazdaság fejlődése szempontjából sem közömbös, hogy milyen minőségủ munkavállalókat bocsát ki az oktatási rendszer, milyen munkára támaszkodhat a gazdaság. Oktatásirányításunk így inkább az öncélú bezárkózás jeleit mutatja, mintsem a korszerü, az egyéni igényekre reagáló, a lemaradókkal is törődő oktatásét. Ha meg is jelennek az oktatási rendszerben ilyen pedagógiai igények, azok támogatottsága a nyilvánosság teljes kizárásával történik, ennek megfelelően a kontrollja sem nyilvános, vagyis nem is kérhető számon a döntéshozókon, így pedig a rendszer az adminisztratív kontroll, vagyis az adminisztratív eredmények irányába tud csak elmozdulni az érdemi változások helyett.

Kötetünkben a tanügyirányítás, a tanügyigazgatás hazai és külföldi folyamataival foglalkozunk. A téma aktualitását a magyar közoktatás irányításában az utóbbi évtizedben bekövetkezett változások adják. Ezek nyomán a korábbihoz képest más célok és más hangsúlyok jelentek meg, a célokhoz pedig (akár a régebbiekhez, akár az újakhoz) más eszközök társulnak. A korábbi, egységes elvekre épülő irányítás mára három részre szakadt: az óvodák, az általános iskolai és a gimnáziumi képzés, valamint az iskolarendszerű szakképzés müködtetése eltérő koncepciók mentén történik. A csaknem egy évtizede kezdődő átalakulás mindenképp indokolja a számvetést: mi miért történt, s milyen hatással járt. Különös jelentőséget ad a témának, hogy tanügyirányításunk egy évtized után is keresi a helyét. Intézményrendszere és intézményeinek hatásköre többször is változott, ami az eredeti elképzelések kiforratlanságára utal, s felveti a kérdést, vajon adekvát válaszokat adtunk-e a megoldandó problémákra.

Bár egységes irányítási modellröl még európai szinten sem beszélhetünk, az egyes országok oktatásirányítása nemcsak közös elemeket tartalmaz, hanem - az eltérő társadalmi, és az intézményrendszert érintő történelmi előzmények ellenére - közös alapvetéseket is. Ilyen például a „központi” és a „helyi” döntések konzisztens egymásra épülésének igénye, a rendszer szakmailag és pénzügyileg hatékony müködtetésére való törekvés, a gazdaság szereplőinek bevonása a szakképzés irányításába, vagy a közismereti oktatás és a szakképzés irányítási rendszerének olyan kialakítása, amely az oktatással kapcsolatos társadalmi célok megvalósulását is szolgálja. Hogy mi tekinthető központi, s mi helyi szintnek, abban már - az adott ország nagyságától, politikai berendezkedésétől, közigazgatási rendszerétől és oktatásirányítási tradícióitól függően jelentős elté- 
rések vannak, mint ahogy az oktatással kapcsolatos társadalmi célok térben és - főként - időben sem feltétlenül azonosak. Ez utóbbiak tekintetében ugyanakkor iránymutatást jelent az Európai Unió mint gazdasági-politikai közösség, s mint olyan közösség, amely részben a közös gazdasági, politikai célok mentén jelöl ki időről időre - leginkább ajánlások formájában - fontos társadalmi célokat. Legyenek ezek általánosak, mint az élethosszig tartó tanulásra, a méltányosságra, a hatékonyságra, a társadalmi kohézió növelésére irányulók, vagy konkrétak, mint a tudásra, a kompetenciákra, az iskolai végzettségre vagy a korai iskolaelhagyásra vonatkozó számszerű referenciaértékek. Nyitva hagyják ugyanakkor az oktatási rendszer, így az iskolarendszerü oktatás irányításának kérdését, de elvárják, hogy ez is szolgálja a közös célokat. Mindezek alapján a külföldi példák, ha nem is tekinthetők konkrét mintának, de iránymutatásnak feltétlenül. Az Educatio e számában éppen ezért mutatjuk be néhány európai ország közoktatás- vagy szakképzés-irányítási rendszerét is, törekedve arra, hogy kirajzolódjanak az ottani változások, s a mögöttük álló társadalmi, gazdasági, s - adott esetben - politikai folyamatok, törekvések.

E külföldi példák tükrében értékelhetők a hazai folyamatok is, amelyek sok tekintetben ellentétesek a legtöbb országéval: olyan célkitűzések kapnak nálunk prioritást, amelyek kevésbé illeszkednek az uniós elvárásokhoz, s amelyekkel összhangban olyan irányítási rendszer lett bevezetve, amely nemcsak ezeket nem szolgálja, de sok tekintetben még a kormányzathoz köthető célkitüzések jelentős részét sem.

\section{IRODALOM}

A Nemzeti köznevelésről (2011) A Nemzeti köznevelésről szóló törvény koncepciója. https://2010-2014.kormany.hu/download/a/b7/50000/Nemzeti_K\%C3\%B6z nevel\%C3\%A9sr\%C5\%911\%20_Sz\%C3\%B31\%C3\%B3_T\%C3\%B6rv\%C3\%A9ny_ Koncepci\%C3\%B3ja_20110930.doc. [Letöltve: 2019. 06. 19.]

A Tanács ajánlása (2015) A Tanács ajánlása (2015. július 14.) Magyarország 2015. évi nemzeti reformprogramjáról, amelyben véleményezi Magyarország 2015. évi konvergenciaprogramját. https://eur-lex.europa.eu/legal-content/HU/TXT/PDF/?uri= CELEX:32015H0818(21)\&from=EN [Letöltve: 2019. 07. 15.]

A Tanács ajánlása (2019) A Tanács ajánlása Magyarország 2019. évi nemzeti reformprogramjáról, amelyben véleményezi Magyarország 2019. évi konvergenciaprogramját. https://hirlevel,egov.hu/2019/07/14/a-tanacs-ajanlasa-magyarorszag-2019-evinemzeti-reformprogramjarol-amelyben-velemenyezi-magyarorszag-2019-evikonvergenciaprogramjat/ [Letöltve: 2019. 07. 15.]

A Tanács következtetései (2009) A Tanács következtetései (2009. május 12.) az oktatás és képzés terén folytatott európai együttműködés stratégiai keretrendszeréről („Oktatás és képzés 2020”). https://eur-lex.europa.eu/legal-content/HU/TXT/HTML/?uri= CELEX:52009XG0528(01)\&from=EN [Letöltve: 2019. 03. 01.]

Council recommendation (2013) Council recommendation of on the National Reform Programme 2012 of Hungary and delivering a Council opinion on the Convergence Programme of Hungary, 2012-2015. https://publications.europa.eu/en/publicationdetail/-/publication/8f0778a5-4a51-4ee4-8dfe-74e18ae4b3a6/language-en [Letöltve: 2019. 07. 15.]

European ideas (2018) European ideas for better learning: the governance of school education systems. The final report and thematic outputs of the ET2020 Working 
Group Schools Produced by the ET 2020 Working Group Schools. Brussel, European Comission.

FazeKas Á., Halász G. \& Horváth L. (2018) Innovációk és innovációs folyamatok a magyar oktatási rendszerben. Educatio, Vol. 27. No. 2. pp. 247-264. https://doi.org/ 10.1556/2063.27.2018.2.7. [Letöltve: 2019. 06. 19.]

First Results (é. n.) First Results from Pisa 2003. Executive summary OECD. http://www. oecd.org/edu/school/programmeforinternationalstudentassessmentpisa/34002454.pdf. [Letöltve: 2019. 06. 16.]

Györgyi Z. (2011) Helyi oktatáspolitikák az ezredfordulón. In: Györgyi Z. (ed.) Korlátok között szabadon. Budapest, OFI.

GyörgY Z Z. (2015) Iskolafenntartás helyi szinten - elözmények és tapasztalatok. In: GyörGyi Z. - Simon M. \& VAdÁsz V. (eds) Szerep-és funkcióváltások a közoktatás világában. Budapest, OFI.

György Z. (2016) Közoktatás-irányítási változatok. Új Pedagógiai Szemle, Vol. 66. No. 5-6. pp. 17-39.

Györgyi Z. \& Köpatakiné Mészáros M. (2011) Oktatási egyenlőtlenségek és sajátos igények. In: Balázs É. - Kocsis M. \& VÁGó I.: Jelentés a magyar közoktatásról 2010. Budapest, OFI.

Halász G. (2011) Oktatáspolitika az első évtizedben. In: Balázs É. - Kocsis M. \& Vágó I.: Jelentés a magyar közoktatásról 2010. Budapest, OFI.

Hermann Z. \& VArga J. (2011) A közoktatás finanszírozása. In: Balázs É. - Kocsis M. \& VÁGó I.: Jelentés a magyar közoktatásról 2010. Budapest, OFI.

Kardos K. \& Kovács K. (2015) „Ez egy civil hőstett volt tulajdonképpen”. In: GyörgY I Z. - Simon M. \& VadÁsz V. (eds) Szerep-és funkcióváltások a közoktatás világában. Budapest, OFI.

Kertesi G. \& Kézdi G. (2009) Általános iskolai szegregáció Magyarországon az ezredforduló után. Közgazdasági Szemle, Vol. LVI. november.

KSH-Stadat: 2.6.1. tábla. https://www.ksh.hu/docs/hun/xstadat/xstadat_eves/i_zoi014. html [Letöltve: 2019. 06. 14.]

Literacy Skills (é.n.) Literacy Skills for the World of Tomorrow. FURTHER RESULTS from PISA 2000. Executive summary. OECD \& UNESCO Institute for Statistics. http://www.oecd.org/edu/school/2960581.pdf. [Letöltve: 2019. 08. 10.]

Literacy Skills (2000) Literacy Skills for the World of Tomorrow: Further Results from PISA 2000 - Publications 2000 http://dx.doi.org/10.1787/888932343285. [Letöltve: 2019. 08, 10.]

Nahalka I. (2017, ed.) Kockás könyv. Van kiút az oktatási katasztrófából. Civil közoktatási platform.

Országos kompetenciamérés (2009) Országos jelentés. https://www.oktatas.hu/pub_bin/ dload/kozoktatas/meresek/orszmer2009/okm_2009_orszagos_jelentes.pdf [Letöltve: 2019. 08. 02.]

Palotás Z. \& Jankó K. (2011) A közoktatás irányítása. In: Balázs É. - Kocsis M. \& VÁGó I.: Jelentés a magyar közoktatásról 2010. Budapest, OFI.

Sáska G. (2013, ed.) Centralizáció, decentralizáció, demokrácia. Educatio, Vol. 22. No. 1. pp. 3-22.

Szabó Z. A. \& Fehérvári A. (2013) A közoktatás fenntartói és finanszírozási változásai a jogszabályok tükrében (2010-2013). Új Pedagógiai Szemle, No. 9-10. 
Széll Kálmán Terv (é. n.) [2011] Összefogás az adósság ellen. URL: http://2010-2014. kormany.hu/download/4/d1/20000/Sz\%C3\%A91l\%20K\%C3\%A1lm\%C3\%A1n\%20 Terv.pdf [Letöltve: 2019. 04. 14.]

SzőKe K. (2011) Mindent egybe. In: György Z. (ed.): Korlátok között szabadon. Budapest, OFI.

Szűcs N. (2013) A hódmezővásárhelyi deszegregációs intézkedés: az oktatási rendszer esélyegyenlőség-fókuszú komplex átszervezése. In: Fejes J. B. \& SzűCs N. (eds) A szegedi és hódmezövásárhelyi deszegregációt támogató hallgatói mentorprogram. Öt év tapasztalatai. Szeged, Belvedere Meridionale.

2011. évi CXC. törvény a nemzeti köznevelésről. https://net.jogtar.hu/ jogszabaly?docid=A1100190.TV. [Letöltve: 2019. 06. 01.]

2016. évi LXXX. törvény az oktatás szabályozására vonatkozó és egyes kapcsolódó törvények módosításáról. https://net.jogtar.hu/jogszabaly?docid=A1600080. TV\&txtreferer=A1100187.TV [Letöltve: 2019. 04. 14.]

134/2016. (VI. 10.) Korm. rendelet az állami köznevelési közfeladat ellátásában fenntartóként részt vevő szervekről, valamint a Klebelsberg Központról

308/2017. (X. 27.) Korm. rendelet az állami köznevelési közfeladat ellátásában fenntartóként részt vevő szervekről, valamint a Klebelsberg Központról szóló 134/2016. (VI. 10.) Korm. rendelet módosításáról.

1382/2017. (VI. 16.) Korm. határozat egyes köznevelési szakmai testületekről.

A cikk a Creative Commons Attribution 4.0 International License (https://creativecommons.org/licenses/ by/4.0/) feltételei szerint publikált Open Access közlemény, melynek szellemében a cikk bármilyen médiumban szabadon felhasználható, megosztható és újraközölhető, feltéve, hogy az eredeti szerző és a közlés helye, illetve a CC License linkje és az esetlegesen végrehajtott módosítások feltüntetésre kerülnek. (SID_1) 